\title{
The Future of Marine Spatial Planning-Perspectives from Early Career Researchers
}

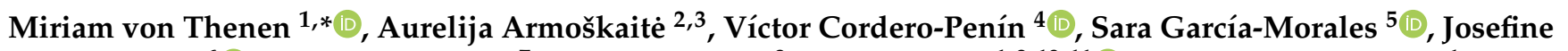 \\ B. Gottschalk ${ }^{6}{ }^{\circ}$, Débora Gutierrez ${ }^{7}$, Malena Ripken ${ }^{8}$, Pascal Thoya ${ }^{1,9,10,11}{ }^{\mathbb{D}}$ and Kerstin S. Schiele ${ }^{1}$ \\ 1 Leibniz Institute for Baltic Sea Research Warnemünde (IOW), 18119 Rostock, Germany; \\ pascalthoya@gmail.com (P.T.); kerstin.schiele@io-warnemuende.de (K.S.S.) \\ 2 Latvian Institute of Aquatic Ecology, 1007 Riga, Latvia; aurelija.armoskaite@lhei.lv \\ 3 Department of Planning, Aalborg University, 2450 Copenhagen, Denmark \\ 4 ECOAQUA Institute, University of Las Palmas de Gran Canaria, 35214 Las Palmas, Spain; \\ victor.cordero89@gmail.com \\ 5 Marine and Environmental Sciences Centre (MARE), Faculdade de Ciências, Universidade de Lisboa, \\ 2750-374 Cascais, Portugal; saragmhurtado@hotmail.com \\ 6 Environmental Assessment \& Planning Research Group, Institute of Landscape Architecture and \\ Environmental Planning, Technische Universität Berlin, 10623 Berlin, Germany; go-fine@gmx.net \\ 7 FGF/UAc/FCT—Fundação Gaspar Frutuoso, Faculty of Sciences and Technology, University of the Azores, \\ 9501-801 Ponta Delgada, Portugal; debora.gutierrez@uac.pt \\ 8 COAST-Centre for Environment and Sustainability Research, Carl von Ossietzky University of Oldenburg, \\ 26111 Oldenburg, Germany; malena.ripken@uni-oldenburg.de \\ 9 Center for Earth System Research and Sustainability (CEN), Institute for Marine Ecosystem and Fisheries \\ Science, University of Hamburg, 22767 Hamburg, Germany \\ check for \\ updates \\ Citation: von Thenen, M.; \\ Armoškaite, A.; Cordero-Penín, V.; \\ 10 Department of Earth and Environmental Sciences, Macquarie University, Sydney, NSW 2109, Australia \\ 11 Kenya Marine and Fisheries Research Institute, Mombasa 80100, Kenya \\ * Correspondence: miriam.thenen@io-warnemuende.de
} García-Morales, S.; Gottschalk, J.B.; Gutierrez, D.; Ripken, M.; Thoya, P.; Schiele, K.S. The Future of Marine Spatial Planning-Perspectives from Early Career Researchers. Sustainability 2021, 13, 13879. https:/ / doi.org/10.3390/su132413879

Academic Editor: Luigi Dell'Olio

Received: 29 October 2021

Accepted: 8 December 2021

Published: 15 December 2021

Publisher's Note: MDPI stays neutral with regard to jurisdictional claims in published maps and institutional affiliations.

Copyright: (c) 2021 by the authors. Licensee MDPI, Basel, Switzerland. This article is an open access article distributed under the terms and conditions of the Creative Commons Attribution (CC BY) license (https:/ / creativecommons.org/licenses/by/ $4.0 /)$.
Abstract: In early 2021, the Erasmus+ knowledge flows partnership organised a session to discuss the future of marine spatial planning (MSP) at an international conference. We, a group of nine early career researchers, came together after the conference to continue the discussion: which topics should be considered in future MSP, what are the challenges, and which solutions are there to overcome these challenges? This communication shall raise awareness of the topics of climate change, ecological sustainability, blue justice, ecosystem services, and blue governance, which we identified as important for future MSP endeavours. We show the interconnectedness of the topics and argue that transdisciplinary education is required to contribute to a common understanding of MSP, which adopts an ecosystem-based approach, ensures equitable distribution of benefits, and secures ecologically sustainable development within an adaptive governance framework.

Keywords: marine spatial planning; MSP education; climate change; ecological sustainability; blue justice; ecosystem services; blue governance

\section{Introduction}

Marine spatial planning (MSP) aims at analysing and allocating "the use of the sea areas to minimise conflicts between human activities and maximise benefits, while ensuring the resilience of marine ecosystems" [1] (p. 23). It thus requires multi-sectoral spatial planning in order to allocate marine space to different maritime activities over time [2] and it should be embedded in the context of wider environmental management to address the spatial and temporal environmental effects of the activities [3]. Spatial planning in the sea furthermore needs to account for a multi-dimensional environment where human activities can take place at the sea bottom, the water column, on or above the surface, and marine resources are varyingly distributed in space and time [4]. 
MSP is an iterative process, which starts with defining a vision and objectives for a planning area, followed by analysing existing conditions and developing future scenarios. After preparing, approving, and implementing the spatial plan, monitoring and evaluation of possible effects takes place and may lead to adapting the plan in turn [5]. It is a complex process to be carried out with the input from relevant stakeholders [6]. The complexity of MSP requires training and education for the responsible parties involved and, at the same time, its transdisciplinary poses challenges when it comes to designing educational and training courses [7]. In higher education, MSP is so far mostly taught as part of other degree programmes [7].

In Europe, the Erasmus+ knowledge flows partnership—a consortium of partners from research and administrative organisations with expertise in MSP-aims at developing a common European education agenda on MSP. As part of this endeavour, the partnership organised a session at the MSP NATURE 2021 conference that took place in January 2021. The session (primarily) aimed at early career researchers to discuss the future of MSP in light of the implementation date of the European MSP Directive. The session provided a platform to exchange and discuss visions and ideas for MSP. We, a group of nine early career researchers, came together after the conference to continue the discussion: which topics should be considered in future MSP, what are the challenges, and which solutions are there to overcome these challenges?

Our team has a diverse and international background; we have studied and researched MSP-related topics in different African, European, and Latin American countries. During our transdisciplinary discussions, several topics arose, which in our view have been neglected or have not been sufficiently addressed in MSP so far. With this commentary, we want to raise awareness of the topics of climate change, ecological sustainability, blue justice, ecosystem services, and blue governance. We are convinced that a shift of thinking is needed for MSP to become truly "effective", as defined by Ehler and Douvere [5], and that these topics need to be considered in future MSP endeavours to fulfil the promise of an ecosystem-based approach to MSP. The ecosystem-based approach considers the entire ecosystem, including humans, strives towards maintaining ecosystems in a "healthy, productive and resilient condition" [5] (p. 24), and may realise strong sustainability [8]. In the following, we present each topic and our perspectives on why it is important for future MSP. As this is a commentary, we do not provide a theoretic underpinning or methodological framework connecting the different topics. Each section covering one topic, however, is structured in the same way: the topic is presented, based on the current literature, the main challenges are summarized, and we highlight potential pathways for including these topics in MSP. While there is certainly no one solution that fits it all, we think that MSP education can make a valuable contribution and, therefore, in the discussion we focus on education and the extent to which it can play a role in supporting these topics by contributing to an MSP-literate community.

\section{Climate Change: Setting the Scene}

Climate change and its potential effects in the ocean are increasingly recognised challenges on the international agenda [9], as they become a momentous threat. Climate controls the abiotic parameters of the ocean, whose alteration leads to changes in the biological conditions [10,11]. It alters ocean circulation patterns [12], affecting the composition of ecosystems $[10,11]$. These variations will also have consequences in key ecosystem services, such as climate regulation, heat absorption, and carbon storage [13]. MSP recognises the need for a balance between the health of marine ecosystems and biodiversity protection with human uses [5]. Still, climate change impacts were not considered until recently, which impeded earlier implementation of adaptation in planning processes [14].

A changing ocean will relocate ecosystem goods and services (e.g., fishing resources), delineate new types of conflicts, and redistribute cumulative environmental impacts [15], so ocean uses will experience spatial and temporal change [16]. By affecting social-ecological systems - i.e., the interactions between the environment and society $[9,17]$ — climate change 
acts as a vulnerability amplifier [14]. Since ocean uses have different economic and social contexts in each region, vulnerability across such systems and uses will also vary differently, therefore considering the spatial aspect in the planning process is of the utmost relevance [16]. This emphasises the need for flexible mechanisms towards adaptive governance [18] - a learning process enabling constant incorporation of new data through the iterative cycles of planning processes, especially through the phases of monitoring and evaluation [5]. Thus, data generation that enables better understanding of the changing marine dynamics in the face of climate change is crucial.

For MSP to become an effective tool in facing climate change, climate change has to be recognised [19] through incorporation into spatial planning processes, from both conceptual and operational perspectives [20]. Marine spatial plans can be key instruments to support sustainable ocean use and conservation [20], when they are aligned with international objectives and environmental policies. Adaptation measures are important regarding their potential in increasing resilience and response capacity in marine social-ecological systems [17], while strong mitigation policies are key to reduce the uncertainty in future emission pathways [21-23]. Considering adaptation measures and mitigation policies in conjunction allows for a better prediction of possible future scenarios to consider in the planning process, thus minimising the maladaptation risk in ocean management $[20,21]$. In addition to the enforcement of climate policy measures, MSP can have a role in mitigation and adaptation actions through the selection of those operational approaches that align with an ecosystem-based approach and also through the so-called nature-based solutions, e.g., protection and restoration of seaweed meadows or mangroves [24-26]. Nature-based solutions have the potential to tackle both the climate and biodiversity crisis as well as contributing to sustainable development [27]. However, there are still uncertainties and lack of evidence regarding the cost-effectiveness of nature-based solutions and sectoral forms of governance prevent the establishment of these solutions as alternatives to grey infrastructures [27].

We consider MSP as a powerful tool to face climate change but state that it cannot be the only solution. MSP can enhance adaptation strategies through effective spatial planning, the allocation of areas for nature-based solutions, and foresightedly deal with the expected increase in conflicts and uncertainties. A spatial perspective is furthermore essential to account for the shifting distribution of species and habitats under a changing climate. However, we believe that all these efforts and resources cannot come at the expense of working towards mitigation strategies resulting from international global agreements and policy actions. We aspire to an MSP that supports an ecosystem-based approach in line with strong sustainability (cf. Section 3), leading to a climate-resilient marine environment, instead of an MSP conditioned by economic growth imperatives. Given the high relevance of climate change for our societies, we think that a strong network of professionals (i.e., scientists/researchers, policy makers, NGOs, public institutions, stakeholders), who cooperate to provide effective solutions towards mitigation and adaptation should be the answer to tackle this challenge. Such networks could also promote the necessary shift in the socio-economic system that is one of the drivers of climate change.

\section{Ecological Sustainability: Planning with the Unknown}

Ecological, or strong, sustainability strives to protect biodiversity and ecosystem functioning and recognises that humans need to live within the planetary boundaries $[8,28]$. In the marine realm, pressing issues such as pollution, biodiversity loss, climate change, and cumulative human pressures emphasise the urgency to use MSP as a tool to foster ecologically sustainable development. Such a development can help build resilient ecosystems and implement nature-based solutions, e.g., counteracting climate change and ensuring ecosystem service provision [28]. Ecological sustainability is inherent to the ecosystem-based approach, which is requested by relevant political frameworks, such as the UN Convention on Biological Diversity or the EU Marine Strategy Framework Directive that asks for the Good Environmental Status [29]. However, in current MSP processes, 
weak sustainability is often favoured over strong sustainability [30] and the integration of environmental aspects receives less attention than the management of user conflicts or the achievement of economic benefits [19,31,32].

When MSP processes adopt a weak sustainability approach, conservation and marineprotected areas can be traded off against other uses, which counteracts an ecosystem-based approach [28,32]. One often-used argument against applying an ecosystem-based approach is the insufficient knowledge base [33]. While there are still knowledge gaps in understanding the functioning of ecosystems, the available knowledge on marine systems needs to be applied [34]. Furthermore, adaptive management and governance can incorporate new information and knowledge as it becomes available [33], which is not only necessary for climate change adaptation (cf. Section 2) but also to include new knowledge on marine ecosystem functioning.

To plan the seas in an ecologically sustainable manner, it is necessary to deal with uncertainties along the data and information generation processes while at the same time trying to close the gaps [33]. Those knowledge gaps need to be addressed actively and cooperatively by science, the society, and politics equally. Biological ocean observations are required to sample data, from which knowledge about changes in and impacts on marine ecosystems can be obtained [35,36]. Ecological maps, mastering the four-dimensional marine environment-i.e., the three-dimensional space plus a temporal dimension [4]should be developed systematically. Such maps should not only include benthic but also pelagic habitats as well as functional ecosystem aspects, such as connectivity and the role of species, e.g., their life cycles and role in the marine food web [12,29]. The ocean is a fluid, highly dynamic, interconnected, and four-dimensional environment with boundless natural properties [37]; however, it is often not addressed as such in marine management [38] and representation of marine space in MSP is usually two-dimensional [34].

The misconception of marine space as a two-dimensional area leads to reductionist analyses of marine systems [34], which, in our view, also fosters reductionist planning. Such planning can result in the allocation of marine space focused (solely) on maritime activities, which impedes effective conservation and management of relevant ecosystem functions. If we want MSP to be the sustainable and holistic tool that it could be [5], planners need to adopt a strong sustainability approach, recognising the planetary, ecological, boundaries [39] of the fluid, dynamic, and "fuzzy" [34] marine environment. In order to achieve an ecosystem approach to MSP, we think that human activities should be allocated based on and according to ecological maps, which represent the four-dimensional marine environment and include ecological and biological data. Where data gaps on marine ecosystems exist, these need to be acknowledged, communicated, and actively addressed throughout the entire planning cycle.

\section{Blue Justice: Ensuring Equity}

Blue justice is an approach to interrogate how the blue economy affects indigenous marine users' historical rights. These rights includes spatial tenure and access rights, environmental and social justice, access rights to food and livelihoods, equity in the distribution of economic benefits, and inclusivity in decision making [40]. MSP, with its focus on stakeholder involvement [5] and the inclusion of generational distributive justice in the strong sustainability approach [8], should be well-suited to address blue justice. However, in practice, MSP has been seen to homogenise all experiences [41] and turn a blind eye to stakeholder power differences and accept tokenistic stakeholder involvement $[42,43]$.

In developing countries, activities that generate more income are often favoured over those with low income, e.g., the preference of tourism to small-scale fisheries activities in the Philippines [44] or the focus on economic gains with little consideration of the needs of local communities in different African countries [45]. Even for developed countries, the MSP process has been shown to fall short in addressing fairness and equity [46]. Lack of equity in planning is also experienced in areas beyond national jurisdiction (ABNJs). The 
development of the international legally binding instrument under the United Natioans Convention on the Law of the Sea is set to be the lead framework in guiding the planning and conservation of the ABNJs. Although the traditional knowledge of indigenous people was incorporated in the process, the communities are still not included in the implementation and decision-making processes [47]; however, it is crucial to include indigenous people and local communities entirely in ABNJ discussions to address social justice issues [48,49].

There are multiple interconnected ecological and socio-economic drivers of change affecting local communities and this complexity may hinder adequate consideration of blue justice in the MSP process. For example, fish stocks shifting due to climate alterations may lead to small-scale fishers losing food security and livelihood [50,51]. In response, smallscale fishers may need to shift their fishing effort, which in turn may lead to new conflicts with other users or potentially increase cumulative impacts on the environment $[15,52]$. Therefore, the ability of MSP to address blue justice issues also relies on the magnitude and effectiveness of implemented climate policies and mitigation and adaptation measures [13]. Planners and decision-makers should adopt climate adaptation that entails more participatory and less hierarchical processes with a consideration of indigenous communities and small-scale fishers [20,53]. Although MSP does not offer a one-stop solution, we believe it can have a relevant role when addressing the climate change-blue justice intersection.

However, there is a need to review MSP critically to ensure it is approached as an adaptive process focused on equity as well as recognising and representing social diversity and the plurality of values [43]. We are convinced that the current balancing of power in the MSP process is insufficient in ensuring that the interests of all stakeholders are safeguarded. A way of achieving more meaningful stakeholder engagement may be the practice of social impact assessments in MSP [54] and by evaluating and operationalising MSP through a social justice perspective [55]. A territorial governance perspective in MSP may also prove useful to address the distribution of power across levels of governance as well as mobilising stakeholders and integrating different interests [56]. We certainly believe that new MSP approaches should go beyond mere involvement, focus on engaging indigenous communities and underrepresented stakeholders, and identify mechanisms that will ensure that those invited to the table are on a par despite their positional power status in society. Because the stakeholder's engagement processes for MSP in developed countries may not apply to developing countries due to socio-cultural and political differences, MSP should furthermore seek to find local solutions to local problems.

\section{Ecosystem Services: Visualising the Value of Marine Ecosystems}

According to an ecosystem services (ES) approach, ecosystems-ecological structures and processes - provide services, which contribute towards human well-being [57]. ES can be used as a framework for understanding human-ecosystem relationships and to implement an ecosystem-based approach in planning through place-based and integrated ES assessments, consisting of supply assessment and benefit analyses $[57,58]$.

ES assessments can support the rendition of social and environmental knowledge into useful terms for marine planning and decision-making $[59,60]$ and help establish ecological maximum sustainable yields that could guide development adjustments within the planet's natural resource limits [39,61]. Simultaneously, ES assessments may support fairer MSP and promote levelling of power relationships among stakeholders through consideration of equitable distribution of benefits, derived from marine ecosystems (cf. Section 4, [54]).

Several studies have shown the value of the ES concept for MSP (e.g., [62-64]). However, implementation of an ES approach into MSP is, in practice, challenging due to gaps in knowledge of marine ecosystems and people's relations to them, a lack of shared understanding of the assessment and implementation process, and disparity around core ES terms [58,65]. Moreover, ES assessments have been mostly conducted on a limited number of services and mostly around easily valued services [66]. This evidences the need for future integrated ES assessments that explicitly consider the co-benefits and/or trade-off relations between multiple ES [65]. Further, some authors warn that excessive reliance 
on quantitative monetary valuation approaches might risk ES being understood from a "utilitarian environmentalism" perspective $[67,68]$. In order to avoid such commodification of nature [69], it is necessary to establish environmental-economic accounting systems [70], which do not undermine community or intrinsic values and explicitly include pluralistic valuations of ES [71,72].

In our view, the use of the ES concept for planning and management can make management decisions more transparent and accessible. To realise this potential, we think it is important to clarify the connection between human inflicted pressures and ES for fully integrated assessments, which consider the whole "production chain", including the effects of demand on the ecosystem and service supply, as well as the ecosystems' vulnerability to cumulative impacts $[66,73]$. Such assessments should be based on various data sources, e.g., expert knowledge complementing existing field datasets. Furthermore, there needs to be clear communication of uncertainties [74], so that uncertainties, e.g., with regard to the shifting distribution of goods and services and their benefits under climate change, are made explicit. In our view, fully integrated ES assessments are a valuable tool to understand the connection between the environment and human well-being and the results of such assessments can be used to communicate, also visually (e.g., [75]), how changes in the goods and services affect society as a whole as well as particular stakeholder groups, such as marginalised communities.

\section{Blue Governance: Towards Social-Ecological Well-Being}

MSP is at the front edge of a new chapter to establish a social discourse in which society (including economy) and nature are reconciled, moving away from traditional sectoral management approaches towards a holistic integrated approach [76].

MSP is a powerful tool to achieve this marine governance transformation [77]. Such a transformation is not only needed within national waters but also in areas that are not yet governed. Despite MSP being applied within national jurisdictions, the growing realisation that there are no borders in a fluid interconnected ocean $[37,38]$ lead to the need of crossborder cooperation and complementary governance mechanisms to properly manage ABNJs [78]. Future MSP initiatives in ABNJs will need an appropriate legal framework that encourages those different bodies to collaborate towards a common view $[79,80]$. Such a collaboration is essential to prevent the loss of biodiversity beyond (and with repercussions within) national jurisdiction [81] and avoid destruction of entire deep-sea ecosystems before even realising they exist [82]. We need to plan using the "best" available, yet potentially flawed, knowledge of marine ecosystems [34,83]. Limited knowledge is often not the main restraint but rigid governance mechanisms and a lack of political will to make controversial decisions in uncertain circumstances [33]. Therefore, management and clear communication of uncertainties in science-based advice are key to foster operationalisation of precautionary approaches and to improve the credibility of governance [74].

Implementation of MSP initiatives tends to be aligned with strategic sectoral priorities (cf. Section 4, [32]) and the assumed rationality and neutrality of MSP practices has been gradually questioned [84]. Thus, MSP is currently failing to reform marine governance in an integrated manner [77]. If MSP applications in practice tend to be mainly guided by blue growth objectives [32], then how sustainable is sustainable MSP and how are we evaluating progress towards sustainability? [85,86].

Being unable to answer this "wicked" question, we argue that a first step towards the answer is to acknowledge that it is greater income equality, rather than economic growth, which drives societal well-being $[87,88]$. Furthermore, we encourage that any future governance transformation is made by acknowledging that decoupling of (green/blue) economic growth from environmental pressure and degradation is being "debunked" [89,90]. Future ocean governance success will ultimately depend on our societal abilities to slowly and profoundly address how to re-humanise the economies and societies [91]. If governance can operate as a modifier of human behaviour for a better future, then how should we combine the diversity of governance incentives (including economic, legal, participation, 
communication, and knowledge) to create a common, effective, equitable, and just future for all? [92].

We argue that future governance in MSP will need to promote shifting from blue growth, which exploits limited resources, to ecologically sustainable development that fosters social equity. The concept of territorial governance with its focus on collaboration, place-based knowledge, and the recognition of soft spaces that are not delimited by administrative boundaries $[56,93,94]$ may prove useful to support this shift. The fact that administrative borders are meaningless from an ecological perspective and that management and policy objectives are a matter of societal choice (Malawi first principle for the EBA) translates in the need to reconcile our societies and reconcile societies with nature. In an imminently public space such as the ocean, we support that the tragedy of the commons is not inherent to humankind but rather occurs when rights and obligations are not equally considered but instead benefit a minority. While (somewhat) harder governance issues need to be clearly improved (e.g., to better work at multi-scales and cross-sectoral levels), we argue that a stronger emphasis should be placed in the softer aspects of governance (e.g., deal with power balance and benefit distribution, build institutional trust, and enhance stakeholders' capacity to meaningfully contribute to decision making) if we want to achieve living within the ecological limits of our planet.

\section{Discussion}

With this communication, we want to raise awareness of topics that we have identified as vital for future MSP: marine management and planning needs to be anticipatory and adaptive - data and scenarios on climate change must be considered and frequently reevaluated in order to tap into the mitigation potential of the oceans and to increase the adaptive capacity of social-ecological systems. The approach to MSP should be truly ecosystem-based-in the sense of a strong sustainability approach (cf. Section 3) - by respecting the ecological boundaries and ensuring an equitable distribution of benefits. As a soft management tool, the ES concept can bridge the gap between the ecological capacity and the socio-economic benefits people can obtain from the sea. At the very least, the ES concept has the ability to visualise and communicate the dependence of human well-being on functioning and healthy ecosystems. Furthermore, a shift of thinking in blue governance is required, moving away from a focus on blue growth towards a focus on social-ecological well-being.

Glimpses of such a shift of thinking have become increasingly visible. At the European level, the new strategy for blue economy argues to change from blue growth to a sustainable blue economy [95]. At the global level, the UN Decade of Ocean Science and the Sustainable Development Goals strive for a sustainable, fair, and prosperous future by acknowledging what sustains us all: nature. In the wake of both the climate and the COVID-19 crisis, the importance of the One Health approach, which recognises the intrinsic connection between the health of humans, animals, and nature [96], becomes eminent. So why do we think that we need to raise awareness for these topics, and which role, indeed, can MSP play in it all?

MSP has been advocated for ensuring a sustainable use of ocean resources while maintaining the value of marine biodiversity [5] and has been suggested to contribute to the UN Ocean Decade [97]. However, in practice, MSP often cannot fulfil its promise of a socially equitable and ecologically sound process [32,42]. The initiation of MSP is often triggered by offshore development projects [32]; challenges of data uncertainties and lack of data, e.g., on marine ecosystem functioning, remain [36,74], and there is a danger of marginalising stakeholders with less power [46]. There is not an easy solution to overcome these challenges; however, we think that education has an important role to play.

In this communication, we show the interconnectedness among these topics: adaptive governance is required to cope with climate change, which can alter the provision of ecosystem services, and ecosystem services can be used to illustrate how shifts in species, resources, and biodiversity affect the distribution of benefits to society with repercussions on the fair and equitable access to the ocean resources and amenities. This interconnect- 
edness calls for transdisciplinary education of MSP professionals and the ability to work transdisciplinarily [7]. In an interconnected world, education needs to bridge boundaries not just across nationalities but also across disciplines.

Common understanding and transdisciplinary approaches on a transnational level for higher education are crucial. The overall aim of such an initiative is to enable students to develop a theoretical, practical, and critical understanding of the notion of MSP and the wider scientific and governance frameworks in which it is being implemented. Dynamic interactions between marine and terrestrial anthropogenic activities are rooted in societal demands. Research to gain a better understanding of the mechanisms behind are related to social as well as to natural sciences. Even though MSP is a legally binding mechanism within the EU [98], it is still relatively new with no classical textbook knowledge [99].

More recently, there has been a move towards providing MSP education $[7,100]$ with still a need for a strong move towards an expansion of MSP higher education [100]. We argue that MSP education should not only be considered a niche topic, which is only touched as part of some educational courses but should rather be moved in the focus of maritime education, with emphasis on full courses and related degree programs at universities, providing students with a solid understanding of spatial planning theories, the origins of MSP, and marine governance, amongst others [100]. The various topics that have been highlighted here exemplify the importance of MSP and its future development. MSP is bringing together heterogeneous groups of students from various interdisciplinary backgrounds and it should be fostered even more that they are educated in working transdisciplinarily. The Erasmus+ partnership tries to develop a common education agenda for MSP higher education and has already succeeded in many ways. Numerous students from different European organisations came together for joint MSP Summer Schools and field trips and benefited from education material that has been developed by lecturers, MSP experts, and practitioners. MSP education is important because only with an MSP-literate community can a common understanding of MSP, which adopts an ecosystem-based approach, ensures equitable distribution of benefits, and secures ecologically sustainable development, be established. Climate change, ecological sustainability, blue justice, ecosystem services, and blue governance are eminent and important topics that need to be emphasised and constantly brought up until they are not only on the political agenda but also find full consideration in MSP practices. In this commentary, we have highlighted some of the challenges for integrating these topics in MSP, including lack of knowledge and data but also a lack of political will to make decisions in uncertain circumstances as well as a lack of equity in planning processes and a disregard for ecological boundaries. However, we are convinced that education can make an important contribution to solving these challenges and that MSP education is vital to garner an MSP-literate community of practitioners and researchers.

Author Contributions: Conceptualization, M.v.T., M.R. and K.S.S.; investigation, M.v.T., A.A., V.C.-P., S.G.-M., J.B.G., D.G., M.R., P.T. and K.S.S.; writing—original draft preparation, M.v.T., A.A., V.C.-P., S.G.-M., J.B.G., D.G., M.R., P.T. and K.S.S.; writing- review and editing, M.v.T., A.A., V.C.-P., S.G.-M., J.B.G., D.G., M.R., P.T. and K.S.S.; project administration, M.v.T.; funding acquisition, M.R. and K.S.S. All authors have read and agreed to the published version of the manuscript.

Funding: Erasmus+ project "Knowledge Flows in Marine Spatial Planning-Sharing Innovation in Higher Education" (grant number KA203-2019-011), which receives funding from the Erasmus+ program of the European Union.

Acknowledgments: This communication emerged from a session at the online conference MSP NATURE 2021. The session was organised by the Erasmus+ project "Knowledge Flows in Marine Spatial Planning-Sharing Innovation in Higher Education". The inspiration and opportunity provided by the conference and in particular by the Erasmus+ session is gratefully acknowledged. We also thank the reviewers for their time and constructive feedback. 
Conflicts of Interest: The authors declare no conflict of interest. The funders had no role in the design of the study; in the collection, analyses, or interpretation of data; in the writing of the manuscript, or in the decision to publish the results.

\section{References}

1. UNESCO-IOC/European Commission. MSPglobal International Guide on Marine/Maritime Spatial Planning; UNESCO: Paris, France, 2021.

2. Grip, K.; Blomqvist, S. Marine spatial planning: Coordinating divergent marine interests. Ambio 2021, 50, 1172-1183. [CrossRef] [PubMed]

3. Smith, H.D.; Maes, F.; Stojanovic, T.A.; Ballinger, R.C. The integration of land and marine spatial planning. J. Coast. Conserv. 2011, 15, 291-303. [CrossRef]

4. Holzhüter, W.; Luhtala, H.; Hansen, H.S.; Schiele, K.S. Lost in space and time? A conceptual framework to harmonise data for marine spatial planning. Int. J. Spat. Data Infrastruct. Res. 2019, 14, 108-132. [CrossRef]

5. Ehler, C.; Douvere, F. Marine Spatial Planning: A Step-By-Step Approach Toward Ecosystem-Based Management; Unesco: Paris, France, 2009.

6. Pomeroy, R.; Douvere, F. The engagement of stakeholders in the marine spatial planning process. Mar. Policy 2008, 32, 816-822. [CrossRef]

7. Gissi, E.; de Vivero, J.L.S. Exploring marine spatial planning education: Challenges in structuring transdisciplinarity. Mar. Policy 2016, 74, 43-57. [CrossRef]

8. Neumann, B.; Ott, K.; Kenchington, R. Strong sustainability in coastal areas: A conceptual interpretation of SDG 14. Sustain. Sci. 2017, 12, 1019-1035. [CrossRef]

9. IPCC. IPCC Special Report on the Ocean and Cryosphere in a Changing Climate; Pörtner, H.-O., Roberts, D.C., Masson-Delmotte, V., Zhai, P., Tignor, M., Poloczanska, E., Mintenbeck, K., Alegría, A., Nicolai, M., Okem, J.A., et al., Eds.; Intergovernmental Panel on Climate Change: Geneva, Switzerland, 2019.

10. IPCC. Climate Change 2014: Impacts, Adaptation, and Vulnerability. Part A: Global and Sectoral Aspects. Contribution of Working Group II to the Fifth Assessment Report of the Intergovernmental Panel on Climate Change; Field, C.B., Barros, V.R., Dokken, D.J., Mach, K.J., Mastrandrea, M.D., Bilir, T.E., Chatterjee, M., Ebi, K.L., Estrada, Y.O., Genova, R.C., et al., Eds.; Cambridge University Press: Cambridge, UK; New York, NY, USA, 2014.

11. Sampaio, E.; Rosa, R. Climate Change, Multiple Stressors, and Responses of Marine Biota. In Climate Action; Leal Filho, W., Azul, A.M., Brandli, L., Özuyar, P.G., Wall, T., Eds.; Springer International Publishing: Cham, Switzerland, 2019; pp. 1-13, ISBN 978-3-319-71063-1.

12. European Marine Board. Navigating the Future V: Marine Science for a Sustainable Future; European Marine Board: Ostend, Belgium, 2019; ISBN 9789492043757.

13. IPCC. An IPCC Special Report on the Impacts of Global Warming of $1.5^{\circ} \mathrm{C}$ above Pre-Industrial Levels and Related Global Greenhouse Gas Emission Pathways, in the Context of Strengthening the Global Response to the Threat of Climate Change, Sustainable Development; Masson-Delmotte, V., Zhai, P., Pörtner, H.-O., Roberts, D., Skea, J., Shukla, P.R., Pirani, A., Moufouma-Okia, W., Péan, C., Pidcock, R., et al., Eds.; Intergovernmental Panel on Climate Change: Geneva, Switzerland, 2018.

14. Craig, R.K. Ocean Governance for the 21st Century: Making Marine Zoning Climate Change Adaptable. Harv. Environ. Law Rev. 2012, 36, 305-350.

15. Frazão Santos, C.; Agardy, T.; Andrade, F.; Crowder, L.B.; Ehler, C.N.; Orbach, M.K. Major challenges in developing marine spatial planning. Mar. Policy 2018, 132, 103248. [CrossRef]

16. Frazão Santos, C.; Agardy, T.; Andrade, F.; Barange, M.; Crowder, L.B.; Ehler, C.N.; Orbach, M.K.; Rosa, R. Ocean planning in a changing climate. Nat. Geosci. 2016, 9, 730. [CrossRef]

17. Bennett, N.J.; Blythe, J.; Tyler, S.; Ban, N.C. Communities and change in the anthropocene: Understanding social-ecological vulnerability and planning adaptations to multiple interacting exposures. Reg. Environ. Chang. 2016, 16, 907-926. [CrossRef]

18. Schultz, L.; Folke, C.; Österblom, H.; Olsson, P. Adaptive governance, ecosystem management, and natural capital. Proc. Natl. Acad. Sci. USA 2015, 112, 7369-7374. [CrossRef]

19. Rilov, G.; Fraschetti, S.; Gissi, E.; Pipitone, C.; Badalamenti, F.; Tamburello, L.; Menini, E.; Goriup, P.; Mazaris, A.D.; Garrabou, J.; et al. A fast-moving target: Achieving marine conservation goals under shifting climate and policies. Ecol. Appl. 2020, 30, e02009. [CrossRef] [PubMed]

20. Frazão Santos, C.; Agardy, T.; Andrade, F.; Calado, H.; Crowder, L.B.; Ehler, C.N.; García-Morales, S.; Gissi, E.; Halpern, B.S.; Orbach, M.K.; et al. Integrating climate change in ocean planning. Nat. Sustain. 2020, 3, 505-516. [CrossRef]

21. Watkiss, P.; Benzie, M.; Klein, R.J.T. The complementarity and comparability of climate change adaptation and mitigation. WIREs Clim. Chang. 2015, 6, 541-557. [CrossRef]

22. Billé, R.; Kelly, R.; Biastoch, A.; Harrould-Kolieb, E.; Herr, D.; Joos, F.; Kroeker, K.; Laffoley, D.; Oschlies, A.; Gattuso, J.-P. Taking Action Against Ocean Acidification: A Review of Management and Policy Options. Environ. Manag. 2013, 52, 761-779. [CrossRef]

23. Stern, N. The Economics of Climate Change: The Stern Review; Cambridge University Press: Cambridge, UK, 2006.

24. Ward, R.D.; Friess, D.A.; Day, R.H.; MacKenzie, R.A. Impacts of climate change on mangrove ecosystems: A region by region overview. Ecosyst. Health Sustain. 2016, 2, e01211. [CrossRef] 
25. Duarte, C.M.; Losada, I.J.; Hendriks, I.E.; Mazarrasa, I.; Marbà, N. The role of coastal plant communities for climate change mitigation and adaptation. Nat. Clim. Chang. 2013, 3, 961-968. [CrossRef]

26. Gattuso, J.-P.; Magnan, A.K.; Bopp, L.; Cheung, W.W.L.; Duarte, C.M.; Hinkel, J.; Mcleod, E.; Micheli, F.; Oschlies, A.; Williamson, P.; et al. Ocean Solutions to Address Climate Change and Its Effects on Marine Ecosystems. Front. Mar. Sci. $2018,5,337$. [CrossRef]

27. Seddon, N.; Chausson, A.; Berry, P.; Girardin, C.A.J.; Smith, A.; Turner, B. Understanding the value and limits of nature-based solutions to climate change and other global challenges. Philos. Trans. R. Soc. B Biol. Sci. 2020, 375, 20190120. [CrossRef]

28. Marques, J.C.; Basset, A.; Brey, T.; Elliott, M. The ecological sustainability trigon-A proposed conceptual framework for creating and testing management scenarios. Mar. Pollut. Bull. 2009, 58, 1773-1779. [CrossRef]

29. European Academies' Science Advisory Council. Marine Sustainability in an Age of Changing Oceans and Seas; European Academies' Science Advisory Council: Brussels, Belgium, 2016; Volume 28.

30. Dom, A.; Belin, A.; Hafdelin, N. A Guide to Maritime Spatial Planning with Nature in Mind; Seas at Risk: Brussels, Belgium, 2019.

31. Merrie, A.; Olsson, P. An innovation and agency perspective on the emergence and spread of Marine Spatial Planning. Mar. Policy 2014, 44, 366-374. [CrossRef]

32. Jones, P.J.S.; Lieberknecht, L.M.; Qiu, W. Marine spatial planning in reality: Introduction to case studies and discussion of findings. Mar. Policy 2016, 71, 256-264. [CrossRef]

33. Murawski, S.A. Ten myths concerning ecosystem approaches to marine resource management. Mar. Policy 2007, 31, 681-690. [CrossRef]

34. Boero, F.; De Leo, F.; Fraschetti, S.; Ingrosso, G. The Cells of Ecosystem Functioning: Towards a holistic vision of marine space. Adv. Mar. Biol. 2019, 82, 129-153. [CrossRef] [PubMed]

35. European Marine Board. Sustaining In Situ Ocean Observations in the Age of the Digital Ocean; European Marine Board: Ostend, Belgium, 2021; Volume 9.

36. Benedetti-Cecchi, L.; Crowe, T.; Boehme, L.; Boero, F.; Christensen, A.; Grémare, A.; Hernandez, F.; Kromkamp, J.C.; Nogueira García, E.; Petihakis, G.; et al. Strengthening Europe's Capability in Biological Ocean Observations; Muñiz Piniella, Á., Kellett, P., Larkin, K., Heymans, J.J., Eds.; European Marine Board: Ostend, Belgium, 2018.

37. Steinberg, P.; Peters, K. Wet ontologies, fluid spaces: Giving depth to volume through oceanic thinking. Environ. Plan. D Soc. Space 2015, 33, 247-264. [CrossRef]

38. Bear, C.; Eden, S. Making space for fish: The regional, network and fluid spaces of fisheries certification. Soc. Cult. Geogr. 2008, 9 , 487-504. [CrossRef]

39. Raworth, K. A Safe and Just Space for Humanity: Can We Live within the Doughnut? Oxfam Discussion Paper; Oxfam: Oxford, UK, 2012.

40. Bennett, N.J.; Cisneros-Montemayor, A.M.; Blythe, J.; Silver, J.J.; Singh, G.; Andrews, N.; Calò, A.; Christie, P.; Di Franco, A.; Finkbeiner, E.M.; et al. Towards a sustainable and equitable blue economy. Nat. Sustain. 2019, 2, 991-993. [CrossRef]

41. Bennett, N.J.; Blythe, J.; White, C.; Campero, C. Blue Growth and Blue Justice; Institute for the Oceans and Fisheries, University of British Columbia: Vancouver, BC, Canada, 2020.

42. Flannery, W.; Healy, N.; Luna, M. Exclusion and non-participation in Marine Spatial Planning. Mar. Policy 2018, 88, 32-40. [CrossRef]

43. Saunders, F.P.; Gilek, M.; Tafon, R. Adding People to the Sea: Conceptualizing Social Sustainability in Maritime Spatial Planning. In Maritime Spatial Planning: Past, Present, Future; Zaucha, J., Gee, K., Eds.; Springer International Publishing: Cham, Switzerland, 2019; pp. 175-199, ISBN 978-3-319-98696-8.

44. Fabinyi, M. The Intensification of Fishing and the Rise of Tourism: Competing Coastal Livelihoods in the Calamianes Islands, Philippines. Hum. Ecol. 2010, 38, 415-427. [CrossRef]

45. Okafor-Yarwood, I.; Kadagi, N.I.; Miranda, N.A.F.; Uku, J.; Elegbede, I.O.; Adewumi, I.J. The Blue Economy-Cultural LivelihoodEcosystem Conservation Triangle: The African Experience. Front. Mar. Sci. 2020, 7, 586. [CrossRef]

46. Flannery, W.; McAteer, B. Assessing marine spatial planning governmentality. Marit. Stud. 2020, 19, 269-284. [CrossRef]

47. UN. Revised Draft Text of an Agreement under the United Nations Convention on the Law of the Sea on the Conservation and Sustainable Use of Marine Biological Diversity of Areas Beyond National Jurisdiction; United Nations: New York, NY, USA, 2020.

48. Mulalap, C.Y.; Frere, T.; Huffer, E.; Hviding, E.; Paul, K.; Smith, A.; Vierros, M.K. Traditional knowledge and the BBNJ instrument. Mar. Policy 2020, 122, 104103. [CrossRef]

49. Weil, M.O. Community Building: Building Community Practice. Soc. Work 1996, 41, 481-499. [CrossRef]

50. FAO. The State of the World Fisheries and Aquaculture-Contributing to Food Security and Nutrition for All; Food and Agricultural Organization of the United Nations: Rome, Italy, 2016.

51. Pecl, G.T.; Araújo, M.B.; Bell, J.D.; Blanchard, J.; Bonebrake, T.C.; Chen, I.-C.; Clark, T.D.; Colwell, R.K.; Danielsen, F.; Evengård, B.; et al. Biodiversity redistribution under climate change: Impacts on ecosystems and human well-being. Science 2017, 355, eaai9214. [CrossRef]

52. Agardy, T. Ocean Zoning: Making Marine Management More Effective; Earthscan Oceans: London, UK, 2010.

53. Bennett, N.J.; Blythe, J.; Sandrine, C.; Campero, C. Blue growth and blue justice: Ten risks and solutions for the ocean economy. Mar. Policy 2021, 125, 104387. [CrossRef] 
54. Frederiksen, P.; Morf, A.; von Thenen, M.; Armoskaite, A.; Luhtala, H.; Schiele, K.S.; Strake, S.; Hansen, H.S. Proposing an ecosystem services-based framework to assess sustainability impacts of maritime spatial plans (MSP-SA). Ocean Coast. Manag. 2021, 208, 105577. [CrossRef]

55. Saunders, F.; Gilek, M.; Ikauniece, A.; Tafon, R.V.; Gee, K.; Zaucha, J. Theorizing social sustainability and justice in marine spatial planning: Democracy, diversity, and equity. Sustainability 2020, 12, 2560. [CrossRef]

56. Moodie, J.R.; Kull, M.; Cedergren, E.; Giacometti, A.; Morf, A.; Eliasen, S.Q.; Schrøder, L. Transboundary marine spatial planning in the Baltic Sea Region: Towards a territorial governance approach? Marit. Stud. 2021, 20, 27-41. [CrossRef]

57. Potschin, M.; Haines-Young, R. Defining and measuring ecosystem services. In Routledge Handbook of Ecosystem Services; Potschin, M., Haines-Young, R., Fish, R., Turner, R.K., Eds.; Routledge: London, UK; New York, NY, USA, 2016; pp. 25-44, ISBN 9781138025080.

58. Ainscough, J.; de Vries Lentsch, A.; Metzger, M.; Rounsevell, M.; Schröter, M.; Delbaere, B.; de Groot, R.; Staes, J. Navigating pluralism: Understanding perceptions of the ecosystem services concept. Ecosyst. Serv. 2019, 36, 100892. [CrossRef]

59. White, C.; Halpern, B.S.; Kappel, C.V. Ecosystem service tradeoff analysis reveals the value of marine spatial planning for multiple ocean uses. Proc. Natl. Acad. Sci. USA 2012, 109, 4696-4701. [CrossRef] [PubMed]

60. Lester, S.E.; Costello, C.; Halpern, B.S.; Gaines, S.D.; White, C.; Barth, J.A. Evaluating tradeoffs among ecosystem services to inform marine spatial planning. Mar. Policy 2013, 38, 80-89. [CrossRef]

61. Bateman, I.J.; Mace, G.M.; Fezzi, C.; Atkinson, G.; Turner, K. Economic Analysis for Ecosystem Service Assessments. Environ. Resour. Econ. 2011, 48, 177-218. [CrossRef]

62. Arkema, K.K.; Verutes, G.M.; Wood, S.A.; Clarke-Samuels, C.; Rosado, S.; Canto, M.; Rosenthal, A.; Ruckelshaus, M.; Guannel, G.; Toft, J.; et al. Embedding ecosystem services in coastal planning leads to better outcomes for people and nature. Proc. Natl. Acad. Sci. USA 2015, 112, 7390-7395. [CrossRef] [PubMed]

63. Guerry, A.D.; Ruckelshaus, M.H.; Arkema, K.K.; Bernhardt, J.R.; Guannel, G.; Kim, C.-K.; Marsik, M.; Papenfus, M.; Toft, J.E.; Verutes, G.; et al. Modeling benefits from nature-Using ecosystem services to inform coastal and marine spatial planning. Int. J. Biodivers. Sci. Ecosyst. Serv. Manag. 2012, 8, 107-121. [CrossRef]

64. Ivarsson, M.; Magnussen, K.; Heiskanen, A.-S.; Navrud, S.; Viitasalo, M. Ecosystem Services in MSP-Ecosystem Services Approach as a Common Nordic Understanding for MSP; Nordic Council of Ministers: Copenhagen, Denmark, 2017; Volume 536.

65. Culhane, F.; Frid, C.; Gelabert, E.R.; Robinson, L. EU Policy-Based Assessment of the Capacity of Marine Ecosystems to Supply Ecosystem Services; ETC/ICM Technical Report 2/2019; European Topic Centre on Inland, Coastal and Marine Waters: Magdeburg, Germany, 2019.

66. Culhane, F.E.; Frid, C.L.J.; Royo Gelabert, E.; White, L.; Robinson, L.A. Linking marine ecosystems with the services they supply: What are the relevant service providing units? Ecol. Appl. 2018, 28, 1740-1751. [CrossRef]

67. Schröter, M.; Stumpf, K.H.; Loos, J.; van Oudenhoven, A.P.E.; Böhnke-Henrichs, A.; Abson, D.J. Refocusing ecosystem services towards sustainability. Ecosyst. Serv. 2017, 25, 35-43. [CrossRef]

68. Muradian, R.; Gómez-Baggethun, E. Beyond ecosystem services and nature's contributions: Is it time to leave utilitarian environmentalism behind? Ecol. Econ. 2021, 185, 107038. [CrossRef]

69. Dempsey, J.; Robertson, M.M. Ecosystem services: Tensions, impurities, and points of engagement within neoliberalism. Prog. Hum. Geogr. 2012, 36, 758-779. [CrossRef]

70. UN. System of Environmental-Economic Accounting 2012-Experimental Ecosystem Accounting; United Nations: New York, NY, USA, 2014.

71. Pascual, U.; Balvanera, P.; Díaz, S.; Pataki, G.; Roth, E.; Stenseke, M.; Watson, R.T.; Başak Dessane, E.; Islar, M.; Kelemen, E.; et al. Valuing nature's contributions to people: The IPBES approach. Curr. Opin. Environ. Sustain. 2017, 26-27, 7-16. [CrossRef]

72. Spash, C.L.; Aslaksen, I. Re-establishing an ecological discourse in the policy debate over how to value ecosystems and biodiversity. J. Environ. Manag. 2015, 159, 245-253. [CrossRef] [PubMed]

73. Griffiths, L.L.; Connolly, R.M.; Brown, C.J. Critical gaps in seagrass protection reveal the need to address multiple pressures and cumulative impacts. Ocean Coast. Manag. 2020, 183, 104946. [CrossRef]

74. Udovyk, O.; Gilek, M. Coping with uncertainties in science-based advice informing environmental management of the Baltic Sea. Environ. Sci. Policy 2013, 29, 12-23. [CrossRef]

75. Armoškaitè, A.; Purina, I.; Aigars, J.; Strāke, S.; Pakalniete, K.; Frederiksen, P.; Schrøder, L.; Hansen, H.S. Establishing the links between marine ecosystem components, functions and services: An ecosystem service assessment tool. Ocean Coast. Manag. 2020, 193, 105229. [CrossRef]

76. Foley, M.M.; Halpern, B.S.; Micheli, F.; Armsby, M.H.; Caldwell, M.R.; Crain, C.M.; Prahler, E.; Rohr, N.; Sivas, D.; Beck, M.W.; et al. Guiding ecological principles for marine spatial planning. Mar. Policy 2010, 34, 955-966. [CrossRef]

77. Clarke, J.; Flannery, W. The post-political nature of marine spatial planning and modalities for its re-politicisation. J. Environ. Policy Plan. 2020, 22, 170-183. [CrossRef]

78. Blasiak, R.; Pittman, J.; Yagi, N.; Sugino, H. Negotiating the Use of Biodiversity in Marine Areas beyond National Jurisdiction. Front. Mar. Sci. 2016, 3, 224. [CrossRef]

79. Wright, G.; Gjerde, K.M.; Johnson, D.E.; Finkelstein, A.; Ferreira, M.A.; Dunn, D.C.; Chaves, M.R.; Grehan, A. Marine spatial planning in areas beyond national jurisdiction. Mar. Policy 2021, 132, 103384. [CrossRef] 
80. Vaughan, D.; Agardy, T. Marine protected areas and marine spatial planning-Allocation of resource use and environmental protection. In Marine Protected Areas. Science, Policy and Management; Humphreys, J., Clark, R., Eds.; Elsevier: Amsterdam, The Netherlands, 2019; pp. 13-35, ISBN 978-0-08-102698-4.

81. Crespo, G.O.; Dunn, D.C.; Gianni, M.; Gjerde, K.; Wright, G.; Halpin, P.N. High-seas fish biodiversity is slipping through the governance net. Nat. Ecol. Evol. 2019, 3, 1273-1276. [CrossRef]

82. Halfar, J.; Fujita, R.M. Danger of Deep-Sea Mining. Science 2007, 316, 987. [CrossRef]

83. Moss, R.H.; Schneider, S.H. Uncertainties in the IPCC TAR: Recommendations to lead authors for more consistent assessment and reporting. In Guidance Papers on the Cross Cutting Issues of the Third Assessment Report of the IPCC; Pachauri, R., Taniguchi, T., Tanaka, K., Eds.; World Meteorological Organization: Geneva, Switzerland, 2000; pp. 33-51.

84. Tafon, R. V Taking power to sea: Towards a post-structuralist discourse theoretical critique of marine spatial planning. Environ. Plan. C Polit. Space 2017, 36, 258-273. [CrossRef]

85. Frazão Santos, C.; Domingos, T.; Ferreira, M.A.; Orbach, M.; Andrade, F. How sustainable is sustainable marine spatial planning? Part I-Linking the concepts. Mar. Policy 2014, 49, 59-65. [CrossRef]

86. Stojanovic, T.A.; Farmer, C.J.Q. The development of world oceans \& coasts and concepts of sustainability. Mar. Policy 2013, 42, 157-165. [CrossRef]

87. Kahneman, D.; Krueger, A.B.; Schkade, D.; Schwarz, N.; Stone, A.A. Would You Be Happier If You Were Richer? A Focusing Illusion. Science 2006, 312, 1908-1910. [CrossRef]

88. Easterlin, R.A. Happiness and Economic Growth-The Evidence. In Global Handbook of Quality of Life: Exploration of Well-Being of Nations and Continents; Glatzer, W., Camfield, L., Møller, V., Rojas, M., Eds.; Springer: Dordrecht, The Netherlands, 2015; pp. 283-299, ISBN 978-94-017-9178-6.

89. Parrique, T.; Barth, J.; Briens, F.; Kershner, C.; Kraus-Polk, A.; Kuokkanen, A.; Spangenberg, J.H. Decoupling Debunked: Evidence and Arguments against Green Growth as a Sole Strategy for Sustainability; European Environmental Bureau: Brussels, Belgium, 2019.

90. Jackson, T. Prosperity without Growth: Economics for a Finite Planet; Earthscan: London, UK; Washington, DC, USA, 2009.

91. Aguilera Klink, F. About the dehumanization of economics and economists. In For the Rehumanization of the Economy and Society; Gutiérrez, N., Aguilera Klink, F., Eds.; Mediterráneo Económico 23; Cajamar Caja Rural: Almería, Spain, 2013 ; pp. 15-28.

92. Khuu, D.T.; Jones, P.J.S.; Ekins, P. Governance analysis of Nha Trang Bay and Cu Lao Cham Marine Protected Areas, Vietnam. Mar. Policy 2021, 127, 104330. [CrossRef]

93. Well, L.v.; Schmitt, P. Understanding territorial governance: Conceptual and practical implications. Eur. Reg. 2015, 21.2013, 209-221.

94. Jay, S. The shifting sea: From soft space to lively space. J. Environ. Policy Plan. 2018, 20, 450-467. [CrossRef]

95. EC. A New Approach for a Sustainable Blue Economy in the EU. Transforming the EU's Blue Economy for a Sustainable Future. Communication from the Commission to the European Parliament, the Council, the European Economic and Social Committee and the Committe of 2021; European Commission: Brussels, Belgium, 2021; p. 21.

96. EC. EU Biodiversity Strategy for 2030. Bringing Nature Back into Our Lives. Communication from the Commission to the European Parliament, the Council, the European Economic and Social Committee and the Committe of the Regions 2020; European Commission: Brussels, Belgium, 2020; p. 23.

97. MSP Forum. MSP as a Contribution to the UN Ocean Science Decade for Sustainable Development. In Proceedings of the Maritime Spatial Planning Forum: Global Meets Regional, Riga, Latvia, 19-21 November 2019.

98. EC. Directive 2014/89/EU of the European Parliament and the Council of 23 July 2014 establishing a framework for maritime spatial planning. Off. J. Eur. Union 2014, 257, 135-145.

99. Behrendt, T.; Ripken, M.; Warmelink, H.; Klenke, T. Maritime Spatial Planning and Integrated Coastal Zone Management in Higher Education: Utilizing the MSP Challenge Serious Game. In Proceedings of the Lecture Notes in Informatics, Gesellschaft für Informatik, Bonn, Germany, 28 September 2021.

100. Jay, S.; Jones, H. Towards a framework for higher education for marine spatial planning. Mar. Policy 2019, 99, 230-238. [CrossRef] 